\title{
Professional military instructor identity in the South African National Defence Force
}

\author{
William Wagner, ${ }^{301}$ Sonja van Putten ${ }^{302} \&$ Willem Rauscher ${ }^{303}$ \\ University of Pretoria
}

\begin{abstract}
In 2015, the chief of human resources at the South African National Defence Force (SANDF) ordered the improvement of the instructional quality and military ethos of military instructors. This article, based on a comprehensive study in this regard, reports on the perceptions of a sample of military instructors in the SANDF on the existence of a construct, known as the professional military instructor identity and its effect on military ethos and instructional quality. A qualitative approach was followed, using an interpretivist/constructivist paradigm, involving data collection by means of a focus group discussion and expert interviews and using thematic networks analysis as data analysis method. A conceptual framework for the professional military instructor identity, consisting of sub-identities, influencing factors and identifying indicators, was constructed. Findings suggest that the professional military instructor identity is not recognised as a construct in the SANDF; however, the elements are known, although only vaguely. The findings also support the view that this situation may have affected the current declining military ethos and instructional quality of military instructors. It is concluded that the institutionalisation and popularisation of the professional military instructor identity, as well as professional recognition of military instructors in the SANDF, could improve the current situation.
\end{abstract}

Keywords: instructional quality, military instructor, identity, military ethos, PMII

\section{Introduction}

As early as 2010, senior educational managers in the South African National Defence Force (SANDF) commented on the decline in instructional quality and military ethos of military instructors. ${ }^{304}$ SANDF chief of human resources (hereafter referred to as CHR) subsequently instructed in September 2015 that the level of training provided to and by military instructors should be improved. ${ }^{305}$ Meanwhile, preliminary investigations at the SANDF College of Educational Technology (SANDF COLET) found no evidence of a professional military identity (PMI) or of a professional military instructor identity (PMII), being discussed or formulated in the SANDF - not even in the latest military policy of the SANDF at the time. ${ }^{306}$

A military instructor is a soldier who, by means of a variety of instructional techniques and media, facilitates learning of other soldiers to acquire competencies for the execution of their unique tasks as modern warriors ${ }^{307}$. One can thus postulate that as a professional, a military instructor should possess a PMII, which, according to Bulei and Dinu, as well as Johansen, is indicative of the work performance of the military instructor, i.e. the more pronounced the PMII, the better the performance of such military instructor. ${ }^{308}$ 
Identity is a concept described as the understandings, feelings and expectations of the overall self in a social position. ${ }^{309}$ According to James, a person has an identity for every position he or she holds in the community ${ }^{310}$ and, says Van Knippenberg, the salient or primary identity has a positive influence on the individual's performance in the relevant position or positions. ${ }^{311}$ Professional identity, being a combination of identities that influence the roles and behaviour that individuals adopt when they perform their work therefore affects individual performance in the workplace. ${ }^{312}$ Likewise, Johansen found that, in the military environment, the PMI of soldiers has a predictive influence on military performance. ${ }^{313}$ Due to its predictive influence on military performance, a lack of a PMII could be the primary reason for the relapse in military ethos and quality of instruction to and by military instructors. ${ }^{314}$

The purpose of the study on which this article reports was to explore the existence of the PMII construct and its effect on the military ethos and quality of instruction to and by military instructors, based on the perceptions of a sample of military instructors in the SANDF. The research was done using an interpretivist/constructivist paradigm and an inductive/qualitative approach. The research design was exploratory in purpose. As methods of data collection, semi-structured conversations, specifically focus group discussions (FGDs), as well as expert interviews were conducted. Thematic networks analysis (TNA) was used as the data analysis method. ${ }^{315}$

\section{Theoretical background}

When appraising existing knowledge on a subject, one maps out a conceptual framework, which can be used to interpret the findings of further research. ${ }^{316}$ Therefore this discussion starts with the view of the overall self, denoted as "Self", leading to the concepts of identity and professional identity as well as a conceptual framework for the PMII, as a specialised derivative of the PMI.

According to James, the Self is a mental construct of how "I" think of "me". ${ }^{317}$ The Self consists of multiple selves, including the social self, physical self, spiritual self and the "pure Ego". ${ }^{318}$ Cooley postulates that the Self is not only influenced by one's view of oneself, but it is inseparably linked to how one perceives the views of others of oneself. ${ }^{319}$ This opinion is confirmed by James, as he describes man's social self, as "the recognition which he gets from his mates". ${ }^{320}$ The need for recognition leads to the Self experiencing the will to succeed, to be acceptable, or to be victorious.

Based on Mead's "self reflects society" dictum, maintaining, "[s]ociety shapes self shapes social behavior", ${ }^{321}$ Stryker and Burke confirm the views of James and Cooley by hypothesising that there is a relationship between the Self and the community. ${ }^{322}$ One has an 'identity' for every position in the community, which can be described as constructions of the past, present and future view of one's self, based on feelings, expectations or understanding of one's social role or position in a group. ${ }^{323}$ Identities are arranged according to a "salience hierarchy", ${ }^{324}$ reflecting the commitment to the role relationships requiring that identity. Furthermore, states Van Knippenberg, one's salient identity motivates one to work for the group interests, which then influences individual performance. ${ }^{325}$ 
Bulei and Dinu define professional identity as "a concept composed by a combination of identities that shape the roles individuals adopt and the ways in which they behave when they perform their work". ${ }^{326}$ They also conclude that professional identity is primarily concerned with work performance, results, and the opinion of others. ${ }^{327}$ Relating to professional identity within an educational context, Beijaard, Meijer and Verloop are of the opinion that professional identity refers to the views of others as well as the view of oneself, based on one's background, experience and what one regards as important in one's work. ${ }^{328}$ Beijaard et al., supported by Day, Kington, Stobart and Sammons, also point out that professional identity is constantly evolving and consists of several subidentities. ${ }^{329}$

Literature with regard to professional identity is mostly context-specific, of which teaching, counselling, nursing, medical, legal and military practices are but a few. Considering the variety of opinions on professional identity, it is postulated that, within the military, the PMI, being the professional identity of a soldier, consists of three elements.

The first element is described by Beijaard et al., Day et al. and Bulei and Dinu as a combination of sub-identities that form the nucleus of the professional identity of the soldier. ${ }^{330}$ Central to the set of sub-identities is the autonomous construct, the Self. This is the core identity and is unique to the individual, while not being influenced by the community. This is the place where the value system resides and is the only identity which distinguishes the individual from all other individuals. ${ }^{331}$ Snider provides the other sub-identities for the soldier, namely the warrior, the military professional, and the leader. The warrior, or war fighter, is skilled in combat and is ready to participate in battle. The military professional executes the orders of government and sees himself ${ }^{332}$ as a servant of the nation. ${ }^{333}$ Organisational values reside in the military professional, which also ensure ethical conduct, competence and teamwork. ${ }^{334}$ Some soldiers, specifically officers and non-commissioned officers, are trained military leaders who have to display enhanced cognitive readiness in order to adapt to and manage the everchanging environment.

The second element of the PMI consists of conceptual constructs, which affect the nature of the identity and are therefore known as influencing factors. Johansen suggests four influencing factors, i.e. idealism, warriorism, professionalism and individualism. ${ }^{335}$ Idealism is based on "strong collectivism, patriotism and altruistic values". ${ }^{336}$ The soldier sees himself, and is seen by the community as the protector of his people and country. Warriorism expresses attitudes toward war fighting, expectations of fighting in a war, and satisfaction when actually fighting in battle. ${ }^{337}$ Professionalism consists of the willingness to participate in peacekeeping operations, known as the expeditionary ethos, the development of skills and execution of operations (operational ethos), as well as team cohesion and fellowship (peer ethos). Military professionalism is characterised by 'noble' characteristics, such as altruism, adherence to shared values and norms, as well as well-honed military and other skills. ${ }^{338}$ Professionalism also breeds a strong organisational culture and self-categorisation. According to Triandis and Gelfland, individualism is characterised by four traits, namely self-definition, the importance 
of personal goals as opposed to group goals, rationality against relatedness, as well as attitudes and norms. ${ }^{339}$ It is also based on modern humanism and displays characteristics such as self-righteousness, opposition to authority, and a breakdown in values. ${ }^{340}$ Individualism often manifests as occupationalism, where the military as an institution becomes an occupation, and self-interest takes precedence over organisational values and motives. ${ }^{341}$ Occupationalism, as explained by Moskos, rejects the idea of a 'calling' or a collective ethos in terms of military service, leading to degradation in the combat readiness of the force. ${ }^{342}$ The SANDF, as an all-volunteer force, displays all the features of occupationalism and the occupational model ${ }^{343}$ It seems that the SANDF is following the trend of other modern armed forces, ${ }^{344}$ such as the Norwegian, British and Israeli armed forces where modern individualism is undermining professionalism. ${ }^{345}$

The third and last element of the PMI consists of identifying indicators, the 'markers' that show the PMI in action, and are observed by the soldier himself, fellow soldiers and society. Snider provides four knowledge clusters, which, when combined with Johansen's performance indicators, provide the four identifying indicators, namely military-technical competence, general military competence, military ethical conduct, as well as leadership and character. ${ }^{346}$

Using the PMI as template, the PMII can also be described in terms of the three identity elements, i.e. the sub-identities, influencing factors, and identifying indicators. The professional identity of a military instructor stems from the dualistic nature of this profession, namely being a soldier and a teacher, and consists of the four PMI subidentities, augmented by elements of a teacher identity, albeit adapted for the military context. ${ }^{347}$ The five sub-identities of a military instructor are therefore the Self, the warrior, the military professional, the leader, and the teacher. The first four sub-identities have been described under the PMI. The teacher sub-identity distinguishes the military instructor from other soldiers. It requires specific educational expertise and the ability of the military instructor to operate effectively and efficiently in various roles according to his rank.

Being a soldier himself, the soldier-related influencing factors for the military instructor remains the same as for the PMI, namely idealism, warriorism, professionalism, and individualism. Analysis of the military influencing factors and teacher influencing factors, such as those provided by Beijaard et al. and Van Putten, shows that military influencing factors embrace the teacher influencing factors as well, for instance the teacher influencing factors 'domain knowledge' and 'teaching context', which can be incorporated in the military influencer's 'professionalism'. ${ }^{348}$ The influencing factors of the PMII thus remain the same as those of the PMI.

Beijaard et al. and Van Putten also provide identifying indicators for the teacher, namely subject matter expertise, teaching and learning expertise, and developmental and nurturing skills. ${ }^{349}$ The identifying factors found in the PMI conceptual framework are military-technical competence, general military competence, military ethical conduct, as well as leadership and character. Military competences, both general and technical, compare with and include subject matter expertise. Teaching and learning competences 
are, however, of such importance to the military instructor that it should be listed separately. This is one of the indicators of a teacher and of a military instructor, and therefore becomes one of the identifying indicators of the PMII. Nurturing students is also integrated in the characteristics of a leader. The five identifying indicators of PMII are therefore military-technical competence, general military competence, military ethical conduct, leadership and character, and teaching and learning competence.

Having provided all the elements of the PMII, both a conceptual framework (see Figure 1) and a definition for PMII can now be formulated.

\section{Conceptual framework and definition}

The nucleus of the conceptual framework of the PMII is the sub-identities with the Self as the central sub-identity. The teacher sub-identity forms the apex, being the defining element of the PMII, while the plinth - solid and unchanging - is formed by the military professional sub-identity. The next layer, the influencing factors, comprises idealism, warriorism, professionalism and individualism, with the teacher influencing factors ingrained in each one. The outer layer consists of five identifying indicators, where military competencies, general and technical, are combined, and teaching and learning competencies are added as alluded to above. Based on its elements, the PMII can be defined as follows:

Professional military instructor identity (PMII) is a construction of the past, present and future perceptions of oneself as a warrior, a leader and a teacher, based on military ethical conduct, general and technical military competence, as well as leadership, character and affiliation with a cohort of military professionals.

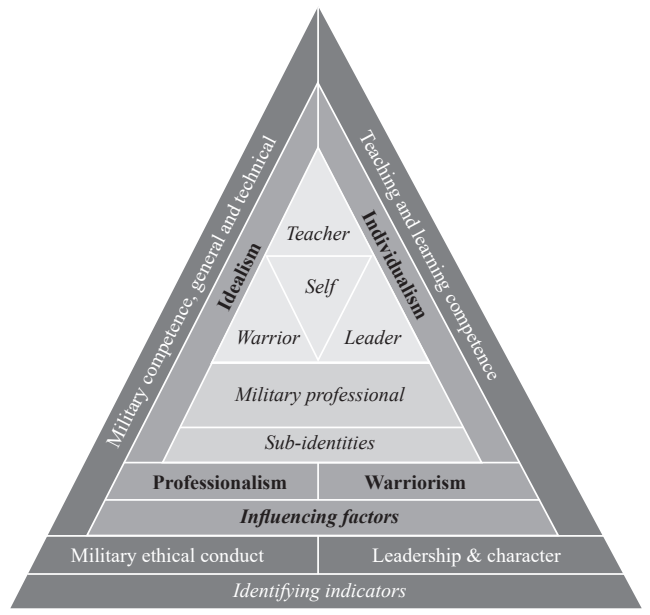

Figure 1. Conceptual framework of the PMII ${ }^{350}$ 


\section{Research methodology}

This research followed a qualitative approach using an interpretivist/constructivist paradigm. A collective case study design was implemented, involving semi-structured conversations and interviews, specifically a FGD and expert interviews, as methods of data collection. As a qualitative research project, non-probability sampling, in particular purposive sampling, was used to select the participants for the FGD and the interviews. ${ }^{351}$

The population from which the participants for the FGD were chosen consisted of all military instructors, stationed in various units throughout South Africa. Since knowledge of different training methods was required to provide informed responses, the sample comprised trained military instructors, attending a retraining programme at SANDF COLET, where additional training methods were taught. The sample originally comprised 20 members, of whom seven withdrew from the FGD for various reasons, such as prior commitments and unwillingness to volunteer. Although slightly more than the number suggested by Richie et al. and Boddy, the interviewer allowed the sample size (now 13 participants) for the FGD, as this size was within the standard practice of the SANDF Military Psychological Institute (MPI). ${ }^{352}$ Even though the researcher had no control over the demographics of the sample, or over the members who were willing to participate in the FGD, the sample was broadly representative of South African demographics and SANDF policy. The FGD was facilitated, audio recorded and transcribed by a research assistant, who was a senior officer in the SA Military Health Service at the time, holding a $\mathrm{PhD}$ in Industrial Psychology and who had conducted numerous FGDs in the course of his career in the SANDF. In order to minimise the effect of military rank, the research assistant, as well as the participants, wore civilian clothes.

For the expert interviews, the population comprised ten members, all former military instructors, being senior officers and warrant officers, serving in senior staff positions at the time or shortly before the FGD, being or having been able to direct military instructor training in the SANDF. Given the thematic focus of the interviews, the limited number of directing posts where the incumbent had an effect on departmental policy and the level of expertise required, a final sample of three participants was interviewed. The interviewees comprised a senior military instructor and two former military instructors, who were senior educational directors in the SANDF at the time. Using the present incumbents in the various posts, demographics were not taken into account. The aim of the interviews was to obtain methodological triangulation and to determine their view with regard to the PMII. ${ }^{353}$ As theoretical saturation was found within the three interviews, it proved to be sufficient. The interviews were conducted by the first author, audio recorded and transcribed.

Thematic analysis, in particular TNA, was used as the data analysis method and coding was done by means of ATLAS.ti 7 Windows, utilising a theory-driven codebook, derived from the conceptual framework of the PMII. ${ }^{354}$ Braun and Clark define thematic analysis as "a method for identifying, analysing and reporting patterns (themes) within data", ${ }^{355}$ which is in agreement with Attride-Stirling, who provided a web-like method for thematic analysis, which she called thematic networks analysis (TNA). ${ }^{356}$ The 
process of TNA extracts themes at different levels from the data and systematically combines them into higher-order themes. There are three classes of themes, starting with the lowest-order theme, known as basic themes, which are synthesised from the textual data, using codes and discussions in the data. By combining basic themes, which are related in terms of similar topics, and a process of abstraction, the next level of themes, called organising themes, is created. The organising themes lead to the over-arching constructs, which capture the important concepts in the data, known as global themes.

\section{Strategies employed to ensure quality data}

Several strategies were employed to ensure quality data. In terms of the trustworthiness, or rigour, of this qualitative study, Lincoln and Guba, as well as Ary, Jacobs, and Sorensen, propose four standards, namely credibility, transferability, consistency and confirmability. ${ }^{357}$ Credibility was ensured firstly by structural corroboration, facilitated by two different sources of data, i.e. FGD and interviews. Secondly, verbatim quotes were used to confirm the coding and theme-building process, thereby confirming referential adequacy, while theoretical adequacy was obtained by voicing all the elements of the PMII in either the FGD or the interviews. Transferability was addressed by a comprehensive description of the participants and interviewees, as well as comparing findings to similar studies as proposed by Norway and Israel. ${ }^{358}$ Consistency implies repeatability, which is relative in a constructivist approach. The study on which this article reports strived for consistency by using so-called 'overlapping methods', such as FGD as well as interviews, and by leaving a detailed description of the method applied in the research, in order to facilitate similar research in any comparable environment. Leaving an audit trail in this manner also facilitated confirmability, which means neutrality and objectivity in the acquisition and analysis of the data and findings.

Before starting with the research, ethical clearance was requested from and granted by the Ethical Committee of the Faculty of Education of the University of Pretoria, as well as the SANDF. Ethical matters, based on the principles of informed consent, voluntary participation, privacy, confidentiality and benevolence were also considered and addressed during the research. ${ }^{359}$ In terms of voluntary participation, all participants were legal adults and volunteers who completed letters of consent. Conditions of privacy and confidentiality were adhered to by appointing a research assistant who, although also being in the SANDF, was unknown to the participants. Anonymity with regard to the inputs in the discussion was guaranteed by the research assistant who transcribed the discussion and did not identify any of the participants. All three interviewees requested anonymity, and are therefore not identified in the research documents. Furthermore, the transcription of the interviews was done by a third party who had no interest in the research. Although the research was done in a strict military environment, every effort was made to create an atmosphere of benevolence while executing the discussion and interviews. The FGD, for example, was conducted in civilian clothes to prevent intimidation by uniform and rank. 


\section{Findings}

The results of the research are reported according to two global themes, following the TNA process of the FGD and three interviews. The first global theme is 'PMII elements exist in the SANDF', which was constructed from four organising themes that stemmed from 14 basic themes. The second global theme, namely 'The PMII and its elements are nebulous', was derived from three organising themes, being the result of eight basic themes (see Table 1). Given the anonymity of the participants of the FGD, quotes will only be labelled as "participant" whereas the three participants in the interviews will be referred to as "Interviewee 1", "Interviewee 2" and "Interviewee 3". Please note that all interviewee responses are reproduced verbatim and unedited.

Table 1. Global themes and their corresponding organising themes

\begin{tabular}{|c|c|}
\hline GLOBAL THEMES & ORGANISING THEMES \\
\hline \multirow{4}{*}{$\begin{array}{l}\text { Global Theme 1: PMII } \\
\text { elements exist in the } \\
\text { SANDF }\end{array}$} & $\begin{array}{l}\text { 1. The military Instructor regards his sub-identities as the } \\
\text { Self, teacher, leader and military professional }\end{array}$ \\
\hline & $\begin{array}{l}\text { 2. PMII influencing factors are idealism, individualism } \\
\text { and professionalism }\end{array}$ \\
\hline & $\begin{array}{l}\text { 3. General and technical military competence, teaching } \\
\text { and learning competence, leadership and character, as } \\
\text { well as military ethical conduct are PMII indicators }\end{array}$ \\
\hline & $\begin{array}{l}\text { 4. These exists socio-political and competency tensions } \\
\text { amoungst elements of the PMII }\end{array}$ \\
\hline \multirow[t]{3}{*}{$\begin{array}{l}\text { Global Theme } 2 \text { : The } \\
\text { PMII and its elements } \\
\text { are nebulous }\end{array}$} & $\begin{array}{l}\text { 1. The military instructor is firstly a warrior and his } \\
\text { professional identity should be founded on military } \\
\text { professionalism }\end{array}$ \\
\hline & 2. Individualism informs a dormant PMII \\
\hline & $\begin{array}{l}\text { 3. Resistance to change prevents the institutionalisation on } \\
\text { the PMII }\end{array}$ \\
\hline
\end{tabular}

\section{Global theme 1: PMII elements exist in the SANDF}

The FGD and interviews confirmed that the construct of a PMI and a PMII does not exist in the SANDF and as such is not discussed, taught or applied. Interviewee 1 alluded to the lack of a PMI as follows:

With regard to the professional military identity, I think it's an area that's currently lacking in the Defence Force [...] it's been shot down I would say since 2000 ... 2001. (Interviewee 1)

During the FGD and the interviews, it was evident that the elements of the PMII, as proposed in the PMII conceptual framework, but not the PMII as a construct, are known and occasionally considered. The focus group participants, however, displayed a 
restricted view of sub-identities. Although the concept of the first sub-identity, the Self, was not fully understood, it was acknowledged as primary and described as follows:

Ja. What I mean by that is that your personal background should reflect through your role as an instructor in class. So, you bring yourself to the class, very honest and you use the same traits. Through your personality to reflect back in your training or teaching style, instructor style (Participant).

The second sub-identity the participants discussed was that of the leader, and they agreed with Snider that the military instructor, as a leader, should display the characteristics of discipline, humility, compassion and a constructivist mind-set. ${ }^{360}$ The third sub-identity, the teacher, was mentioned twice during the FGD, but only vaguely and not in the context of a sub-identity, as alluded to by Dynes. ${ }^{361}$ In terms of the fourth sub-identity, namely the military professional, the participants confirmed Snider's view that the military professional is the servant of the nation with strict organisational values, ethical conduct and discipline. ${ }^{362}$ Contrary to the less experienced instructors in the focus group, who regarded the Self as the primary sub-identity, the more experienced Interviewee 2 and Interviewee 3 viewed the military professional as the primary sub-identity:

[T] he military instructor is always firstly defined in terms of his ... own ... mustering or the corps that he belongs to ... (Interviewee 3)

In terms of sub-identities, the participants discussed the Self and the leader and made hardly any references to the teacher and the military professional. Mention of the warrior was purely incidental. Concerning this lack of a warrior identity, Interviewee 1 had a specific view:

I would say that the warrior its ... soldiers these days is more to do with work and getting paid than being a warrior. (Interviewee 1)

Without realising that the four concepts, namely idealism, individualism, warriorism and professionalism, are the influencing factors of the PMII, the participants discussed three of the factors, namely idealism, individualism and professionalism. ${ }^{363}$ Idealism, encompassing elements such as altruism, patriotism, esprit de corps and a military value system, as well as professionalism, which involves motivation towards the task at hand and self-development, were both only briefly implied in the discussion. Individualism, based on self-righteousness and opposition to authority, was associated with democratic conduct and regarded as follows:

And now ... from my experience, I have seen people been so dynamical and tyrants nè, and in their way to ... their way or no way. So, it is important that now you should be democracy ... (Participant)

Having broadly mentioned the sub-identities and the influencing factors, the participants briefly described the identifying indicators of the PMII, expressing a strong view that military instructors should be "specialists" with regard to their general and technical 
military competences. With regard to teaching and learning competences, the participants argued the merits of a qualification. Although some realised that a qualification does not guarantee competence, they were predominantly of the opinion that teaching and learning competences can be equated to a qualification.

Leadership and character, as well as military ethical conduct were all mentioned by some of the participants, strongly defending the virtues of discipline, honesty and integrity:

Your yes is your yes, and your no is your no, and it cannot be changed to suit the person, to suit the situation, and to suit your own circumstances. If you want people to learn something from you, you need to be trustworthy. They need to know that they are safe with you. That there are parameters, if they overstep the parameters, you need to take charge and sort it out and bring them back. There is nothing wrong with disciplining people or being autocratic, or being assertive when people are doing something wrong. (Participant)

To conclude therefore, most of the PMII elements are known in the SANDF, but it is undefined, un-institutionalised, does not constitute a PMII, and does not contribute to military instructor performance in a direct or structured way.

\section{Global theme 2: The PMII and its elements are nebulous}

The first factor contributing to the vagueness of the PMII and its elements is the absence of a pronounced teacher and warrior sub-identity. Interviewee 2 was the first participant to mention an important factor that specifically has an influence on the teacher subidentity, namely that any soldier in the SANDF acting as a military instructor does so for a limited period of time. He thereby identified the military professional as the primary sub-identity.

I'd like to distinguish between professional instructor identity [...] in a military sense being subject to the professional identity of that individual as a military professional ... first, in my view, firstly, the instructor identity is subject to the professional identity whether that person is a pilot or a doctor or an infanteer or whatever ... that is the [...] longerterm determinant for the person's [...] identity and this view is based on my personal conviction that the person that is utilised as ... as the instructor is not use ... utilised in the military over an extended period of time in his or her career. (Interviewee 2)

Interviewee 3 held the same view as Interviewee 2, namely that the military instructor is firstly a warrior and his or her identity is founded on military professionalism. In spite of the high regard that Interviewee 3 held for PMII, she, like Interviewee 2, was of the opinion that the PMI is dominant. In terms of PMII, one can conclude that the warrior and military professional guides the PMII, which is consistent with the views of Snider, but contrary to the view of the less experienced instructors, who regarded the Self as the primary sub-identity, adding to the uncertainty and nebulousness with regard to the PMII sub-identities. ${ }^{364}$ 
Of importance with regard to the influencing factors, Interviewee 1 confirmed the view expressed during the FGD, namely that military instructors primarily display individualism. He was of the opinion that individualism weakens warriorism and professionalism, which it is detrimental to the current military ethos, and that professionalism should receive more prominence in training. Interviewee 2 agreed with Interviewee 3 and shared the view of Ben-Dor et al. regarding the detrimental effect of increasing individualism in modern societies and armed forces. ${ }^{365}$ Interviewee 2 was of the opinion that South Africa and the SANDF are following suit, contributing to the vagueness of the PMII and its elements.

Interviewee 2 was also very clear about the detrimental effect of resistance to change in training theory and methodology and the effect of resistance to change on the lack of military ethos and the quality of instruction provided to and by military instructors:

Maybe the overriding factor is that the dominant theories at the time and still prevailing ... are historical frames of reference that ... emanated from a non-military environment ... and in fact, it may regress to the same framework that has led to chief HR's decision ... in 2015 to address the lack of expertise and competence amongst our instructors ... we're not correcting the problem. (Interviewee 2)

\section{Discussion}

The purpose of the study on which this article is based, was to explore the existence of the PMII construct and its effect on the military ethos and quality of instruction to and by military instructors, based on the perceptions of a sample of military instructors in the SANDF. A conceptual framework of the PMII, comprising three elements, namely sub-identities, influencing factors, and identifying indicators, was used to determine the perceptions of military instructors on the PMII construct, its existence, and its effect on the military ethos and quality of instruction of military instructors in the SANDF.

Analysis of the results of the discussion with a focus group consisting of trained instructors at the SANDF COLET, as well as interviews with senior military instructors and educational directors, being former military instructors, using TNA, is supportive of the elements of the PMII, although inconsistent with regard to its significance. The construct of a PMII was, at the time of writing, unknown in the SANDF. Although most of the participants were trained as combat or combat support soldiers, the absence of a warrior ethos emanating from the discussion was particularly obvious. The participants discussed their position in civilian terms and were more concerned with qualifications than with competence and with democratic leadership than with professionalism. The views on individualism confirmed that, at the time, the SANDF was following the trend of other modern armed forces, where modern individualism is perceived to undermine professionalism and warriorism. ${ }^{366}$ Uncertainty with regard to the importance of subidentities and resistance to change pertaining to the training of military instructors obscured the issue of a PMII in the SANDF even further. 
Given Van Knippenberg's understanding that the presence of an identity, connected to a social group, leads to individual performance, as well as Johansen's view that the PMI has a predictive influence on the performance of soldiers, it might be expected that the lack of a PMII could provide the basis for the decline in the performance of military instructors. ${ }^{367}$ McKinlay and Nuciari assert that a profession, with its professional identity, is characterised by several indicators, namely a theoretical and practical body of knowledge, autonomy and self-control, a unique ethic, and a professional body. ${ }^{368}$ The lack of instructional performance to and by military instructors, as indicated by the CHR, is consistent with the absence of a professional identity and a theoretical and practical body of knowledge. ${ }^{369}$ The same argument applies for the lack of a unique military ethos, which is in keeping with the want of a unique ethic.

\section{Conclusion}

In conclusion, the study indicated the need for an institutionalised PMII in the SANDF and the promotion of professionalism and warriorism to the extent required. The institutionalisation of the PMII could be through official doctrine, openly supported by the Chief of the SANDF. In addition, the explanation and popularisation of the PMII could be done by means of a document similar to the US Army Profession of Arms and through motivational events, such as ceremonies. ${ }^{370}$ This conclusion also indicates the need for visual recognition through competency badges and monetary recognition by means of an instructor allowance. Both methods for recognition are already mentioned in a CHR instruction. ${ }^{371}$

According to Johansen, identity can be used to predict certain elements of performance. ${ }^{372}$ Further research into the predictive potential of the PMII could therefore be of value to the SANDF. Given the growing individualism in the SANDF and the views of Van Knippenberg and Johansen, research with regard to the effect of individualism would also provide valuable inputs in the attempt to improve the military ethos and the training of and by military instructors. ${ }^{373}$

The study reported here explored the proverbial unchartered waters to contribute to the body of knowledge of military education and training. This could lead to the enhancement of the military ethos and the effectiveness of the training of and by military instructors in order to improve training in the SANDF, thereby saving soldiers' lives. The findings support the poignant adage at the SANDF COLET:

"Behind every good soldier there is an even better instructor" 


\section{ENDNOTES}

${ }^{301}$ Brigadier General (Dr) William J Wagner, SA Army (ret) is a contract lecturer at the Faculty of Education of the University of Pretoria. Before retiring from the SANDF in 2017, he was the Commandant (General Officer Commanding) of the SANDF College of Educational Technology (COLET). The results in this article are based on his $\mathrm{PhD}$ thesis, "Professional military instructor identity and the effect of collaborative instructivism", supervised by Prof. Van Putten and Prof. Raucher.

302 Prof. Sonja van Putten is an associate professor at the Department of Science, Mathematics and Technology Education in the Faculty of Education at the University of Pretoria. Her field of research is professional identity of those who teach.

${ }^{303}$ Prof. Willem Rauscher is an associate professor at the Department of Science, Mathematics and Technology Education in the Faculty of Education at the University of Pretoria. His field of research is the process of design, including the design of teaching structures.

${ }^{304}$ South African Department of Defence. CHR Instruction: HR Development: Directorate ETD Systems Integrity: Accreditation \& Quality Insurance: 003/10: Profile, selection, appointment, training and rotation of instructors and directing staff at DOD ETD providers. Pretoria, 2010.

${ }^{305}$ South African Department of Defence. Decision brief to CHR on the transformation of the training of military instructors by adopting and integrating digital learning. COLET/R/103/2. Pretoria, SANDF, 2015.

${ }^{306}$ South African Department of Defence. South African Defence Review. Pretoria, 2015; South African Department of Defence. Chief Human Resources Instruction 04/2018 Military Instructor Management System and Learning Path dd 06 Feb 18. Pretoria, 2018.

${ }^{307}$ Military educational managers and directors are mostly military instructors promoted to a management level and are therefore included in the collective known as military instructors, except where exclusion or specification is required.

${ }^{308}$ I Bulei \& G Dinu. "From identity to professional identity: A multidisciplinary approach". In Proceedings of the 7th International Management Conference, Bucharest, 2013, 249258; R Johansen. "The impact of military identity on performance in the Norwegian Armed Forces". PhD dissertation. University of Bergen, 2013.

${ }^{309}$ J Stets \& P Burke. "A sociological approach to self and identity". In MT Leary (ed), Handbook of self and identity. New York, NY: Guilford Press, 2003, 128-152.

${ }^{310}$ W James. The principles of psychology. New York, NY: Henry Holt, 1890.

${ }^{311}$ D van Knippenberg. "Work motivation and performance: A social identity perspective". Applied Psychology 49/3. 2000. 357-371.

${ }^{312}$ Bulei \& Dinu op. cit.

${ }^{313}$ Johansen op. cit.

${ }^{314}$ Ibid

315 J Attride-Stirling. "Thematic networks: An analytic tool for qualitative research". Qualitative Research 1(3). 2001. 385-405.

${ }^{316}$ J Mouton. How to succeed in your master's \& doctoral studies: A South African guide and resource book. Pretoria: Van Schaik, 2001; J Creswell. Research design (4 ${ }^{\text {th }}$ ed). Lincoln, NA: Sage, 2014.

317 James op. cit., p. 292

${ }^{318}$ James op. cit., p. 292

${ }^{319}$ N Rousseau. Self, symbols \& society. Lanham, MD: Rowman \& Littlefield, 2002.

${ }^{320}$ James op. cit., p. 293. 
${ }^{321}$ S Stryker \& P Burke. “The past, present, and future of an identity theory”. Social Psychology Quarterly Special Millennium Issue on the State of Sociological Social Psychology 63/4. 2000. 284-297.

${ }^{322}$ Ibid.; James op. cit.; Rousseau op. cit.

${ }^{323}$ Ibid.

${ }^{324}$ Ibid., p. 286.

${ }^{325}$ Van Knippenberg op. cit.

${ }^{326}$ Bulei \& Dinu op. cit., p. 254.

327 Ibid.

${ }^{328}$ D Beijaard, P Meijer \& N Verloop. "Reconsidering research on teachers' professional identity". Teaching and Teacher Education 20. 2004. 107-128.

${ }^{329}$ Ibid.; C Day, A Kington, G Stobart \& P Sammons. "The personal and professional selves of teachers: Stable and unstable identities". British Educational Research Journal 32/4. 2006. 601-616.

${ }^{330}$ Beijaard et al. op. cit.; Day et al. op. cit.; Bulei \& Dinu op. cit.

${ }^{331} \mathrm{~J}$ Hewitt. Self and society: A symbolic interactionist social psychology $\left(7^{\text {th }} \mathrm{ed}\right)$. Boston, MA: Allyn \& Bacon, 1997; S Hitlin. "Values as the core of personal identity: Drawing links between two theories of self". Social Psychology Quarterly 66/2. 2003. 118-137; D Oyserman. "Identity-based motivation: Implications for action-readiness, proceduralreadiness, and consumer behavior". Journal of Consumer Psychology 19/3. 2009. $250-260$.

${ }^{332}$ For ease of reading, masculine nouns and pronouns are being used; however, it does not refer to a single gender exclusively.

${ }^{333}$ D Snider. "Officership: The professional practice”. Military Review January-February 2003. 3-8.

${ }^{334}$ Ibid.

${ }^{335}$ Johansen op. cit.

${ }^{336}$ Ibid., p. 19.

${ }^{337}$ Ibid.

${ }^{338}$ Ibid.

${ }^{339} \mathrm{H}$ Triandis \& M Gelfand. "Converging measurement of horizontal and vertical individualism and collectivism". Journal for Personality and Social Psychology Vol 74, No 1. 1998. $118-128$.

${ }^{340}$ Johansen op. cit.

${ }^{341}$ C Moskos. "Institution vs occupation: Contrasting models of military organisation". Woodrow Wilson International Center for Scholars, 1981. <http://www.dtic.mil/dtic/tr/fulltext/ u2/a096966.pdf> Accessed on 1 June 2017.

${ }^{342}$ Ibid.; J Faris. "The looking-glass army: Patriotism in the post-Cold War era". Armed Forces \& Society 21/3. 1995. 411-434; J Griffith. "After 9/11, what kind of reserve soldier? Armed Forces \& Society 35/2. 2009. 214-240.

${ }^{343}$ South African Department of Defence. South African Defence Review 1998. Pretoria, 1998; South African Department of Defence, South African Defence Review 2015 op. cit.

${ }^{344}$ L Heinecken. "The military, war and society: The Achilles heel of sociology and the need for reflection". Inaugural lecture, 11 February 2014. <http://scholar.sun.ac.za/ handle/10019.1/86806> Accessed on 8 June 2017; A Esterhuyse. "Educating for professionalism: A new military for a new South Africa". Scientia Militaria 34/2. 2006. 135-151. 
${ }^{345}$ R Johansen, J Laberg \& M Martinussen. "Military identity as predictor of perceived military competence and skills". Armed Forces \& Society 40/3. 2014. 521-543; J Dynes.

"Professionalism and practice: The development of situational, vocational professional identity amongst UK Army reserve instructors". PhD dissertation. University of

Brighton, 2014; G Ben-Dor, A Pedahzur, D Canetti-Nisim, E Zaidise \& A Perliger. "I versus we: Collective and individual factors of reserve service motivation during war and peace". Armed Forces \& Society Vol 40(3). 2008. 565-592.

${ }^{346}$ Snider op. cit.; Johansen op. cit.

${ }^{347}$ Dynes op. cit.

${ }^{348}$ Beijaard et al. op. cit.; S van Putten. "Professional Mathematics teacher identity in the context of pre-service training". PhD dissertation. University of Pretoria, 2011.

${ }^{349}$ Beijaard et al. op. cit.; Van Putten op. cit.

${ }^{350}$ Source: Author's own compilation

${ }^{351}$ J Ritchie, J Lewis, C McNaughton Nicholls \& R Ormston. Qualitative research practice. Los Angeles, CA: Sage, 2014; R Stake. "Case studies”. In NK Denzin \& YS Lincon (eds), Handbook of qualitative research. London: Sage, 1994, 236-247.

${ }^{352}$ Ibid.; C Boddy. "A rose by any other name may smell as sweet but 'group discussion' is not another name for a 'focus group', nor should it be". Qualitative Market Research: An International Journal 8/3. 2005. 248-255; LA Meyer, personal communication, 12 February 2019.

${ }^{353}$ U Flick. Managing quality in qualitative research. Los Angeles, CA: Sage, 2007.

${ }^{354}$ Attride-Stirling op. cit.

${ }^{355}$ V Braun \& V Clarke. "Using thematic analysis in psychology". Qualitative Research in Psychology 3. 2006. 77-101.

${ }^{356}$ Attride-Stirling op. cit.

${ }^{357}$ Y Lincoln \& E Guba. Naturalistic inquiry. Thousand Oaks, CA: Sage, 1985; D Ary, L Jacobs $\&$ C Sorensen. Introduction to education research $\left(8^{\text {th }} \mathrm{ed}\right)$. Belmont, CA: Wadsworth, 2010.

${ }^{358}$ Johansen op. cit.; Ben-Dor et al. op. cit.

${ }^{359}$ Mouton op. cit.

${ }^{360}$ Snider op. cit.

${ }^{361}$ Dynes op. cit.

${ }^{362}$ Snider op. cit.

${ }^{363}$ Johansen op. cit.

${ }^{364}$ Snider $o p$. cit.

${ }^{365}$ Ben-Dor et al. op. cit.

${ }^{366}$ Heinecken op. cit.; Esterhuyse op. cit.

${ }^{367}$ Van Knippenberg op. cit.; Johansen op. cit.

${ }^{368} \mathrm{R}$ McKinlay. "Professionalization, politicization and civil-military relations". Mens \& Maatschappij 45/6. 1970. 393-408; M Nuciari. "Rethinking the military profession: Models of change compared". Current Sociology 42/3. 1994. 7-21.

${ }^{369}$ South African Department of Defence, Decision Brief to CHR ... op. cit.

${ }^{370}$ Department of the Army. The profession of arms. Fort Eustis: TRADOC, 2010.

${ }^{371}$ South African Department of Defence, Chief Human Resources Instruction op. cit.

${ }^{372}$ Johansen op. cit.

${ }^{373}$ Van Knippenberg op. cit.; Johansen op. cit. 